\title{
Heavy Metals Concentrations in Fish from Sicily (Mediterranean Sea) and Evaluation of Possible Health Risks to Consumers
}

\author{
Chiara Copat $\cdot$ Francesca Bella $\cdot$ Marine Castaing $\cdot$ \\ Roberto Fallico • Salvatore Sciacca • \\ Margherita Ferrante
}

Received: 3 June 2011/Accepted: 11 October 2011/Published online: 22 October 2011

(C) The Author(s) 2011. This article is published with open access at Springerlink.com

\begin{abstract}
Cadmium, lead, mercury and chromium concentrations in fish muscle tissue taken from various Sicilian areas were detected. Fish caught in Siracusa, nearby a petrochemical industrial area, were more contaminated by cadmium, lead and chromium (respectively 0.366, 0.32, $0.72 \mu \mathrm{g} / \mathrm{g}$ ) than those from the other sites. In the Sicily Channel, we found the highest bioaccumulation of mercury $(0.31 \mu \mathrm{g} / \mathrm{g})$. Although some metals concentrations exceed the limits set by the European regulation, the estimated weekly intake was below the Provisional Tolerable Weekly Intake established by the European Food and Safety Authority, and the Target Hazard Quotient values indicate that there is no carcinogenic risk for humans.
\end{abstract}

Keywords Fish · Pollution · EWI - THQs

Sicily is the Mediterranean Sea largest island. Thanks to its location and its heterogeneous habitat, it is characterized by a rich marine biodiversity. Fish are widely consumed, firstly because they are part of the local diet, but also because of their high protein, low saturated fat and omega fatty acids content, that are known to contribute to good health (Kennedy et al. 2009).

In Sicily the main pollution sources are certainly attributable to the three biggest industrial sites: Augusta, in

C. Copat $(\bowtie) \cdot$ F. Bella $\cdot$ M. Castaing $\cdot$ R. Fallico .

S. Sciacca $\cdot$ M. Ferrante

Department of Hygiene and Public Health "G.F. Ingrassia",

University of Catania, Via Santa Sofia 87, 95123 Catania, Italy

e-mail: chiaracopat@hotmail.com

C. Copat

Ketos Scientific Association, Viale Mario Rapisardi 210,

95100 Catania, Italy the central east coast (Ionian Sea), Gela in the south coast (Sicilian channel) and Milazzo in the north east coast (Tyrrhenian Sea). These areas are known for producing pollutants from refining oil, wastewater and toxic dust from heavy metals (Madeddu and Sciacca 2008).

Though the Palermo area (north west of Sicily) has a variety of industrial and commercial activities (such as oil and electric power production systems, and engineering, shipbuilding, manufacturing companies), its primary source of contaminants derives from urban and harbour activities. Moreover, agricultural and domestic effluents contribute to make it one of the most contaminated areas along the Mediterranean coasts.

Fish absorb heavy metals from the surrounding environment (Ginsberg and Toal 2009) depending on a variety of factors such as the characteristics of the species under consideration, the exposure period, the concentration of the element, as well as abiotic factors such as temperature, salinity, $\mathrm{pH}$ and seasonal changes. Hence, harmful substances like heavy metals, released by anthropogenic activities will be accumulated in marine organisms through the food chain; as a result, human health can be at risk because of consumption of fish contaminated by toxic chemicals.

For this reason, fish muscle is commonly analysed to determine contaminants concentrations.

The aim of this study was to verify the concentrations of $\mathrm{Cd}$, $\mathrm{Pb}, \mathrm{Hg}$ and $\mathrm{Cr}$ in muscles of commercial fish species Engraulis encrasicolus (European anchovy) Sardina pilchardus (European pilchard) and Mullus barbatus (Red Mullet).

The species analyzed are very important from an economic point of view for the Sicilian region but also throughout Italy, accounting for $18 \%$ of the total seafood production, in particular $8.86 \%$ for E. encrasicolus, $5.67 \%$ for S.pilchardus and $3.46 \%$ for M. barbatus (ISTAT 2000). 
Studies on heavy metals bioaccumulation on fish is now widespread, but in recent years the risk factors' calculation for the population become of great importance, because although sometimes the contaminants exceed the legal limits set by European regulations for food, not always represent a risk for human health. For that reason, we estimated the weekly intake comparing it with the Provisional Tolerable Weekly Intake (PTWI) recommended by the European Food Safety Authority (2004, 2009, 2010) and the Target Hazard Quotient (THQs) provided in the US-EPA Region III risk-based concentration table (US-EPA 2000b), in order to evaluate possible alert regarding human health hazards.

\section{Materials and Methods}

In April 2007, 30 fish samples per site were taken from fishing boats in four areas with different anthropogenic and natural impact (Fig. 1); they were stored frozen till analysis.

The sampled species were adults of E. encrasicolus $(E e)$ in Siracusa (SR), Mazzara del Vallo (MA), San Vito lo Capo (SA) and Catania (CT); S. pilchardus (Sp) in Catania (CT) and Pantelleria (PA); and M. barbatus $(M b)$ only in Pantelleria (PA). Pantelleria was chosen as control area, as it is a small island in the middle of the Sicily Channel, not directly subject to sources of anthropogenic pollution. Samples were brought to the laboratory where we investigated the presence of $\mathrm{Cd}, \mathrm{Hg}, \mathrm{Cr}$ and $\mathrm{Pb}$.

For the lab tests $1 \mathrm{~g}$ of muscle tissue per fish was mineralized in a microwave system Ethos TC (Milestone S.r.1._ITALY) after tissue digestion using a heated

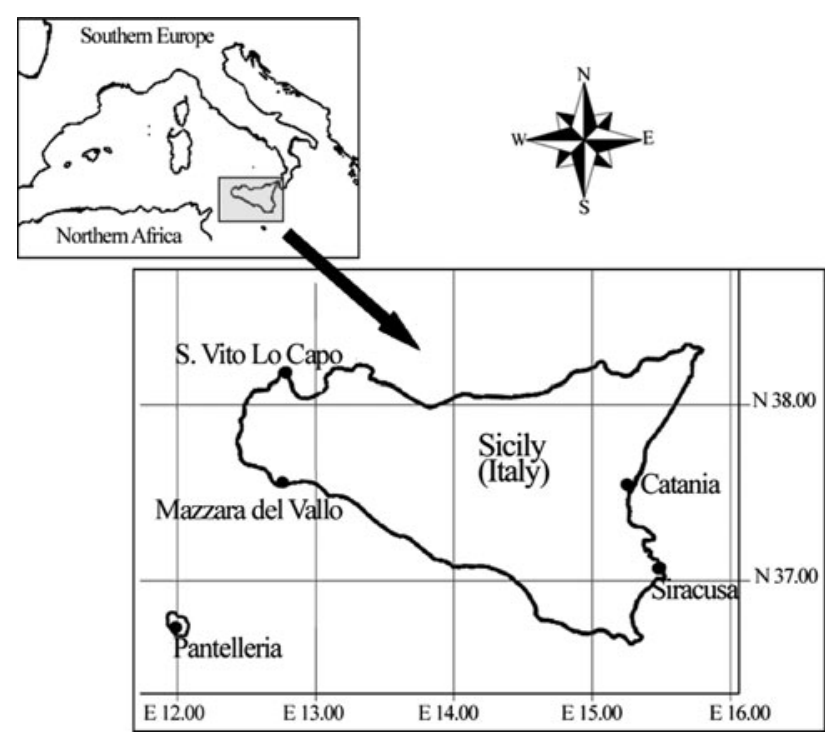

Fig. 1 Map of Sicily. Black dots indicate the sample areas mixture of strong acids. A digestion solution was prepared with $6 \mathrm{~mL}$ of nitric acid $\left(\mathrm{HNO}_{3}\right) 65 \%$ (Carlo Erba) and $2 \mathrm{~mL}$ of peroxide hydrogen $\left(\mathrm{H}_{2} \mathrm{O}_{2}\right) 30 \%$ (Carlo Erba) with a 50 min operation cycle at $200^{\circ} \mathrm{C}$. After mineralization, ultra pure water (Merck) was added to the samples up to $20 \mathrm{~mL}$; they were then divided into two aliquots: one for $\mathrm{Hg}$ measurement and one for the other metals. The sample for $\mathrm{Hg}$ analysis was oxidized with $5 \%$ potassium permanganate $\left(\mathrm{KMnO}_{4}\right)$, then neutralized with hydroxylamine hydrochloride $\left(\mathrm{NH}_{2} \mathrm{OH} \cdot \mathrm{HCl}\right) 1.5 \%$; this strong oxidation allows the conversion of organic $\mathrm{Hg}$ into inorganic $\mathrm{Hg}$. The test was performed with a FIAS 100 (Perkin-Elmer, USA) using the cold vapor capture technique. For the quantification of $\mathrm{Cd}, \mathrm{Cr}$, and $\mathrm{Pb}$ an atomic absorption spectrophotometer AAnalist-800 (Perkin-Elmer, USA) was used. Analytical blanks were run in the same way as the samples and concentrations were determined using standard solutions prepared in the same acid matrix. Standards for the instrument calibration were prepared on the basis of monoelement certified reference solution ICP Standard (Merck).

Standard reference material Lake Superior fish 1946 NIST was also used to validate analysis (Table 1). $\mathrm{Cr}$ reference value was not specified in the analysis certificate of the Standard reference material used, so we assumed a recovery similar to that of the other elements.

The risk for human health as a result of eating these species was evaluated by calculating daily $\mathrm{Hg}, \mathrm{Cd}, \mathrm{Cr}$ and $\mathrm{Pb}$ exposure $\mathrm{E}_{\mathrm{m}}$ (US-EPA 2000a)

$\mathrm{E}_{\mathrm{m}}=\left(\mathrm{C}_{\mathrm{m}} * \mathrm{IR}_{\mathrm{d}}\right) / \mathrm{BW}$

$\mathrm{C}_{\mathrm{m}}$ represents the metal concentration in seafood $(\mu \mathrm{g} / \mathrm{g}), \mathrm{IR}$ the daily ingestion rate $(\mathrm{g} / \mathrm{d})$ of seafood and $\mathrm{BW}$ the body weight $(\mathrm{kg})$. Dietary exposure was expressed as $\mu \mathrm{g} / \mathrm{kg}$.

The average seafood consumption suggested by the National Statistical Institute for Italy (ISTAT 2000) is $60 \mathrm{~g}$ per day, but Sicilian population is a high-level seafood consumer, as its diet is highly dependent on seafood items. For this reason we consider $10 \mathrm{~g}$ more than the value suggested by ISTAT, as did Di Leo et al. (2010) for Taranto population of south Italy. Therefore, if we make allowance of $70 \mathrm{~g}$ as the total seafood intake per day, on the basis of species production data provided by ISTAT (2000), we can assume a day intake, respectively, of $6 \mathrm{~g}$ for E. encrasicolus (42 $\mathrm{g}$ of $\mathrm{IR}_{\mathrm{w}}$ ), $4 \mathrm{~g}$ for $S$. pilchardus $(28 \mathrm{~g}$ of $\left.\mathrm{IR}_{\mathrm{w}}\right)$ and $2.5 \mathrm{~g}$ for $M$. barbatus $\left(17.5 \mathrm{~g}\right.$ of $\left.\mathrm{IR}_{\mathrm{w}}\right)$.

Table 1 Reference concentration values of standard reference material 1946 NIST $(\mu \mathrm{g} / \mathrm{g}$, w.w.)

\begin{tabular}{llll}
\hline & $\mathrm{Pb}$ & $\mathrm{Cd}$ & $\mathrm{Hg}$ \\
\hline Certified & 0.70 & $2.08 \times 10^{-3}$ & 0.433 \\
Found & 0.65 & $2.01 \times 10^{-3}$ & 0.398 \\
\hline
\end{tabular}


We calculated the Estimated Weekly Intake (EWI) as follows:

$\mathrm{EWI}=\left(\mathrm{C}_{\mathrm{m}} * \mathrm{IR}_{\mathrm{W}}\right) / \mathrm{BW}$

where $\operatorname{IR}_{\mathrm{w}}$ is the weekly ingestion rate $(\mathrm{g} / \mathrm{w})$.

Target Hazard Quotient (THQ) values were also calculated according to the report of (US-EPA 2000b), indicating the ratio between exposure and the reference dose. The THQ calculations were made using the standard assumption for an integrate US-EPA risk analysis, considering an adult average body weight of $60 \mathrm{~kg}$ (Di Leo et al. 2010). Additionally, based on the US-EPA guidance (1989), we assume that the ingestion dose is equal to the adsorbed contaminant dose and that cooking has no effect on the contaminants (Chien et al. 2002)

$$
\begin{aligned}
\mathrm{THQ}= & {[(\mathrm{EFr} \cdot \mathrm{EDtot} \cdot \mathrm{IFR} \cdot \mathrm{C}) /(\mathrm{RfDo} \cdot \mathrm{BWa} \cdot \mathrm{ATn})] } \\
& \cdot 10^{-3}
\end{aligned}
$$

EFr is the exposure frequency (350 days/year); EDtot is the exposure duration ( 80 years for the Italian population according to ISTAT (Demo Istat.it 2011); IFR is the food ingestion rate (g/day) (as for $\mathrm{E}_{\mathrm{m}}$ ); $\mathrm{C}$ is the concentration $(\mu \mathrm{g} / \mathrm{g})$; RfDo is the oral reference dose $(\mu \mathrm{g} / \mathrm{g} /$ day); BWa is the adult body weight $(60 \mathrm{~kg})$; ATn is the average time for non carcinogens (it is equal to EFr $\times$ EDtot).

The European Protection Agency has declined to set a RfDo for $\mathrm{Pb}$ because it has found no evidence of a threshold below which a non harmful intake could be "allowed" (US-EPA 2004); as a consequence, THQ for $\mathrm{Pb}$ was calculated with the following equation (Liu et al. 2009):

$\mathrm{THQ}=\mathrm{C} / \mathrm{MRL}$

where $\mathrm{C}$ is the metal concentration in food $(\mu \mathrm{g} / \mathrm{g})$ and MRL (Maximum Regulation Limit) is the limit set by the European Community (2006). The EC Regulation has set for $\mathrm{Hg}, \mathrm{Cd}$, and $\mathrm{Pb}$ a limit concentration in muscle tissue of fresh fish, above which this is considered unsuitable for human consumption. There is no EC information about maximum $\mathrm{Cr}$ levels.

Furthermore, while US EPA set RfDo for Cr(III) and for $\mathrm{Cr}$ (VI) (see Table 2), our investigation looked at total $\mathrm{Cr}$; considering that $\mathrm{Cr}(\mathrm{VI})$ is more toxic, we referred our

Table 2 RfDo (US EPA) and MRL (EC regulation) ( $\mu \mathrm{g} / \mathrm{g}$, w.w.)

\begin{tabular}{lll}
\hline & RfDo & MRL \\
\hline $\mathrm{Cr}$ & $1.5[\mathrm{Cr}(\mathrm{III})] ; 3.0[\mathrm{Cr}(\mathrm{VI})]$ & $/$ \\
$\mathrm{Cd}$ & $1.0 \times 10^{-3}$ & 0.05 \\
$\mathrm{Hg}$ & 0.01 & 0.5 \\
$\mathrm{~Pb}$ & $/$ & 0.02 \\
\hline
\end{tabular}

results to its $\mathrm{RfDo}$, assuming that the $\mathrm{Cr}$ we found is all Cr(VI)

Because some of the variables were not normally distributed, statistical analyses were carried out with nonparametric Wilcoxon Rank Sum test, applying $p=0.001$ as the highest level of significance.

\section{Results and Discussion}

Our results show (see Table 3) that traces of $\mathrm{Hg}$ were found in all samples, $\mathrm{Cd}$ and $\mathrm{Cr}$ were found in all samples except those from $\mathrm{CT}, \mathrm{Pb}$ was found only in samples from SR and CT.

The amount of $\mathrm{Pb}$ found in E. encrasicolus exceeded the limit set by the EC Regulation $(0.20 \mathrm{ppm})$ in $62.5 \%$ of the fish analyzed in SR and in $12.5 \%$ of the fish analyzed in CT. Pb mean in E. encrasicolus was, therefore, higher than the EC Regulation limit only in SR. Some $\mathrm{Pb}$ traces were found in the $S$. pilchardus sample group from CT. Overall, in $60 \%$ of the analyzed fish, Cd exceeded the limit set by the EC Regulation. All fish from SR, Ma and Sa had higher concentrations, as it had $50 \%$ of the S. pilchardus and $75 \%$ of the M. barbatus from PA, whereas both species from CT were not contaminated. The $S$. pilchardus from PA, as expected in a control area, is less contaminated than the E. encrasicolus from SR, MA and SA (all $p=0.005$ ). Inversely, $\mathrm{Cd}$ in $S$. pilchardus from PA was significantly higher than that found in fish muscle of $S$. pilchardus and E. encrasicolus from CT $(p=0.005$ and $p=0.008$, respectively).

Samples from SR and SA had Cr mean level higher than those from the other sites. E. encrasicolus from SR and from SA had higher levels than S. pilchardus from PA ( $p=0.005$ and $p=0.008$, respectively). Though the E. encrasicolus from MA was more contaminated then the $S$. pilchardus from $\mathrm{Pa}$, the difference was not statistically significant ( $p=0.38$ ); inversely, the latter was more contaminated than both species from CT $(p=0.05$ for E. encrasicolus and $p=0.39$ for $S$. pilchardus).

Overall, only $4 \%$ of the samples had $\mathrm{Hg}$ concentrations higher than the limit set by the EC Regulation, therefore the resulting $\mathrm{Hg}$ pattern is different than the other metals. Surprisingly, in the $S$. pilchardus sampled from the control area of $\mathrm{Pa}$ we found a value significantly higher than those found in the sample groups from SR $(p=0.005)$, in the S. pilchardus from CT $(p=0.005)$, in the E. encrasicolus from CT $(p=0.005)$, from Sa $(p=0.02)$ and from $\mathrm{Ma}$ $(p=0.02)$, and in the M. barbatus from $\mathrm{Pa}(p=0.005)$. $\mathrm{Hg}$ bioaccumulation was more relevant in $S$. pilchardus than in E. encrasicolus from CT ( $p=0.02)$.

Results show an obvious contamination in the samples taken in Siracusa, which is located $20 \mathrm{~km}$ south from the 


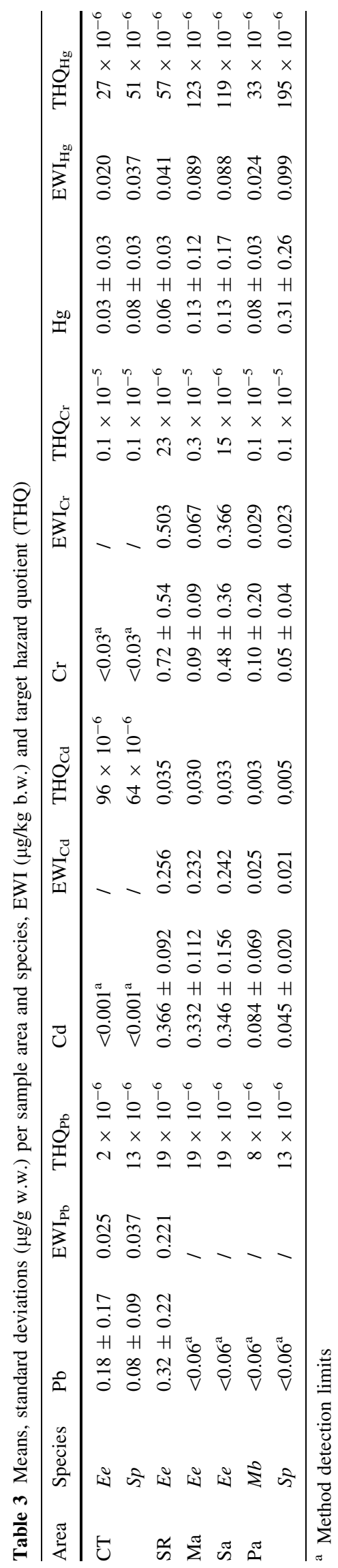

large industrial complex of Augusta-Priolo-Melilli, where there is a well documented bioavailability of contaminants such as heavy metals, PCBs and PAHs, correlated with congenital malformations and abortions (Madeddu and Sciacca 2008). The Siracusa sea receives lot of water laden with pollutants from that industrial site, due to the surface downward current of the Ionian sea.

In three (Siracusa, Mazzara Del Vallo and San Vito Lo Capo) of all sites we studied, we found a marked Cd contamination, due to industrial activities in the south east area, and to intense agricultural activities in the western area.

In the samples from Pantelleria, chosen as control area, bioaccumulation is not as low as expected, especially if we compare it to the sampling area of Catania, which, despite having a greater human impact, has been found generally to be less contaminated than Pantelleria. In particular, in the control area, we found high $\mathrm{Hg}$ concentrations. Though in a seemingly uncontaminated area this may appear unusual, it seems that the presence of that element is due to volcanoes, fumaroles and submarine tectonic activity in the Mediterranean basin, especially in the area of the Sicily Channel and Southern Tyrrhenian Sea (Di Leonardo et al. 2006). In a study on heavy metals bioaccumulation in the M. barbatus sampled in Capo Passero (an area in the Sicily Channel with low anthropogenic impact), authors found a $\mathrm{Hg}$ concentration (Mean: $0.31 \mathrm{mg} / \mathrm{kg}$ w.w.) exceeding that of most man-made sites (Storelli and Marcotrigiano 2005). Furthermore, in a study conducted in the eastern Aegean sea (Kucuksezgin et al. 2001), authors found in the M. barbatus levels of $\mathrm{Hg}$ ranging from 0.016 to 0.2 with a mean of $0.090 \mathrm{mg} / \mathrm{kg}$ (w.w.). The results from our Pantelleria samples range from 0.056 to 0.086 with a mean of $0.083 \mathrm{mg} / \mathrm{kg}$ (w.w.) in M. barbatus, and from 0.090 to 0.324 with a mean of $0.306 \mathrm{mg} / \mathrm{kg}$ (w.w.) in S.pilchardus.

Results obtained from the Catania area are satisfactory, as they are not significantly different than those from the control area of Pantelleria, except for $\mathrm{Pb}$. Our data are in accordance with a previous study on bioaccumulation of heavy metals in Parablennius sanguinolentus sampled along the Catania coastline (Tigano et al. 2009).

$\mathrm{Cd}$ and $\mathrm{Pb}$ concentrations we observed in E. encrasicolus are lower than those reported in other studies carried out in the Eastern Mediterranean area (Yildirim et al. 2009), found $\mathrm{Cd}$ and $\mathrm{Pb}$ mean concentrations in muscle tissue of the same specie of 1.88 and 2.15 ( $\mu \mathrm{g} / \mathrm{g}$ w.w.), instead $\mathrm{Cr}$ mean concentration was below the detection limit; the same trend results were found in muscle of S. pilchardus from the north east Mediterranean sea (Canli and Atli 2003), with a $\mathrm{Cd}, \mathrm{Cr}$ and $\mathrm{Pb}$ mean concentration of $0.55,2.22$ and 5.57 ( $\mu \mathrm{g} / \mathrm{g}$ d.w.). Instead, a study carried out in the Adriatic Sea on E. encrasicolus (Sepe et al. 2003) reported $\mathrm{Cd}, \mathrm{Cr}$, and $\mathrm{Pb}$ values equal, respectively, to $0.020,0.083$ and 0.046 ( $\mu \mathrm{g} / \mathrm{g}$ w.w.), less than the 
concentrations we observed in the same species in the group from $\mathrm{SR}$ for the three metals, in $\mathrm{CT}$ for $\mathrm{Pb}$, in the sample group from $\mathrm{Sa}$ and $\mathrm{Ma}$ for $\mathrm{Cd}$ and $\mathrm{Cr}$.

The European Food Safety Autority (EFSA) has established regulatory guidelines regarding dietary mercury, cadmium and lead intake. It recommends a PTWI of $1.6 \mu \mathrm{g} / \mathrm{kg}$ b.w., $7 \mu \mathrm{g} / \mathrm{kg}$ b.w. and $25 \mu \mathrm{g} / \mathrm{kg}$ b.w. for $\mathrm{Hg}, \mathrm{Cd}$ and $\mathrm{Pb}$, respectively.The PTWI value of $\mathrm{Cr}$ is $637 \mu \mathrm{g} / \mathrm{kg}$, that it equal to the minimum requirement of a person per $\mathrm{kg}$ of body weight (De et al. 2010).

As shown in Table 3 our EWI are below PTWI concentrations, so even if $\mathrm{Cd}$ concentration found in muscle fish are above the limit set by European regulation, this is not a risk for human health, but it needs a continuous monitoring of contamination level.

We also calculated the THQs with RfDo set by EFSA for $\mathrm{Cr}, \mathrm{Hg}$ and $\mathrm{Pb}$, and with MRL set by the EC Regulation for Cd. THQs results indicate that there is no carcinogenic risk (see Table 3). THQs values below 1 mean, in fact, that the level of exposure is smaller than the reference dose; we can, therefore, assume that the daily intake shown by our results at this stage is not likely to cause any deleterious effect during lifetime in humans.

Data we found well reflect the expected level of contamination in the sampling areas, in relation to the natural contributions and to those of anthropic origin. The fish we analyzed reveal some metals concentrations potentially toxic if they enter the food chain. However, since their toxicity for humans is given by the ingestion rate, data we obtained on EWI and THQs indicate that the concentrations we found in the sampled fish don't represent a risk for human health. Of course, it is just a first step; fish contamination levels should be carefully monitored on a regular basis, to detect any change in their patterns that could become a hazard to human safety. Furthermore, in order to have more data on bio-accumulation, the investigation should be extended to other sampling stations with other pelagic as well as benthic species, considering that the latter are more reliable for this task.

Acknowledgments Thanks to Ketos Scientific Association, and especially Dr. Letterio Mario Tringali, supporting us during the sampling procedures.

Open Access This article is distributed under the terms of the Creative Commons Attribution Noncommercial License which permits any noncommercial use, distribution, and reproduction in any medium, provided the original author(s) and source are credited.

\section{References}

Canli M, Atli G (2003) The relationships between heavy metal (Cd, $\mathrm{Cr}, \mathrm{Cu}, \mathrm{Fe}, \mathrm{Pb}, \mathrm{Zn}$ ) levels and the size of six Mediterranean fish species. Environ Pollut 121:129-136
Chien LC, Hung TC, Choang KY, Yeh CY, Meng PJ, Shieh MJ, Ha BC (2002) Daily intake of TBT, Cu, Zn, Cd and As for fishermen in Taiwan. Sci Total Environ 285:177-185

De TK, De M, Das S, Ray R, Ghosh PB (2010) Level of heavy metals in some edible marine fishes of mangrove dominated tropical estuarine areas of Hooghly River, North East Coast of Bay of Bengal, India. Bull Environ Contam Toxicol 85:385-390

Demo Istat.it (2011) Speranza di vita alla nascita e a 65 anni, per sesso e regione-Anni-2007-2010. Available via DIALOG. http://demo.istat.it/altridati/indicatori/2010/Tab_5.pdf. Accessed 07 Oct 2011

Di Leo A, Cardellicchio N, Giandomenico S, Spada L (2010) Mercury and methylmercury contamination in Mytilus galloprovincialis from Taranto Gulf (Ionian Sea, Southern Italy): Risk evaluation for consumers. Food Chem Toxicol 48:3131-3136

Di Leonardo R, Tranchida G, Bellanca A, Neri R, Angelone M, Mazzola S (2006) Mercury levels in sediments of central Mediterranean Sea: a 150+ year record from box-cores recovered in the Strait of Sicily. Chemosphere 65:2366-2376

EC (2006) Commission Regulation N. 1881/2006 of 19 December 2006. Setting maximum levels of certain contaminants in foodstuff. Off J Eur Union Legis Ser 64:5-24

EFSA (2004) Opinion of the scientific panel on contaminants in food chain on a request from the commission related to mercury and methylmercury in food. EFSA J 34:1-14

EFSA (2009) Cadmium in food. (Request N EFSA-Q-2007-138) (adopted on 30 January 2009) scientific opinion of the panel on contaminants in the food chain. EFSA J 980:1-139

EFSA (2010) Scientific opinion on lead in food (request N. EFSA-Q2007-137) (adopted on 18 March 2010) EFSA panel on contaminants in the food chain (CONTAM). EFSA J 8:1570

Ginsberg GL, Toal BF (2009) Quantitative approach for incorporating methylmercury risks and omega-3 fatty acid benefits in developing species-specific fish consumption advice. Environ Health Perspect 117:267-275

ISTAT (2000) Statistica sulla pesca, caccia e zootecnia. Alba Grafica Spa, Roma

Kennedy A, Martinez K, Chuang CC, LaPoint K, McIntosh M (2009) Saturated fatty acid-mediated inflammation and insulin resistance in adipose tissue: mechanisms of action and implications. J Nutr 139:1-4

Kucuksezgin F, Altay O, Uluturhan E, Kontas A (2001) Trace metal and organochlorine residue levels in red mullet (Mullus barbatus) from the eastern Aegean, Turkey. Water Res 35:2327-2332

Liu F, Ge J, Hu X, Fei T, Li Y, Jiang Y, Xu Z, Ding S, Giesy JP, Pan J (2009) Risk to humans of consuming metals in anchovy (Coilia sp.) from the Yangtze River Delta. Environ Geochem Health 31:727-740

Madeddu A, Sciacca S (2008) Biological tracking on the presence of $\mathrm{Hg}, \mathrm{PCB}$ and HCG in milk and hair of women resident in a region with high incidence of children born with malformation (Augusta). Ann Ig 20:59-64

Sepe A, Ciaralli L, Ciprotti M, Giordano R, Funari E, Costantini S (2003) Determination of cadmium, chromium, lead and vanadium in six fish species from the Adriatic Sea. Food Addit Contam 20:543-552

Storelli MM, Marcotrigiano GO (2005) Bioindicator organisms: heavy metal pollution evaluation in the Ionian Sea (Mediterranean Sea-Italy). Environ Monitor Assess 102:159-166

Tigano C, Tomasello B, Pulvirenti V, Ferrito V, Copat C, Carpinteri G, Mollica E, Sciacca S, Renis M (2009) Assessment of environmental stress in Parablennius sanguinolentus (Pallas, 1814) of the Sicilian Ionian coast. Ecotoxicol Environ Saf 72:1278-1286

US-EPA (1989) Risk assessment guidance for superfund volume I Human health evaluation manual (Part A), Interim final. EPA/ 
540/1-89/002. United States Environmental Protection Agency, Washington

US-EPA (2000a) Guidance for assessing chemical contamination data for use in fish advisories volume II Risk assessment and fish consumption limits. EPA/823-B94-004. United States Environmental Protection Agency, Washington

US-EPA (2000b) Risk-based concentration table. United States Environmental Protection Agency, Philadelphia
US-EPA (2004) Lead and compounds (inorganic). United States Environmental Protection Agency, Washington

Yildirim Y, Gonulalan Z, Narin I, Soylak M (2009) Evaluation of trace heavy metal levels of some fish species sold at retail in Kayseri, Turkey. Environ Monitor Assess 149:223-228 